\title{
ALGORITMA FLOYD WARSHALL UNTUK MENENTUKAN JALUR TERPENDEK EVAKUASI TSUNAMI DI KELURAHAN SANUR
}

\author{
AJENG FitRAH SANi ${ }^{1}$, Ni KetUt TARi TASTRAWATI ${ }^{2}$, I MADE EKa DWIPAYANA ${ }^{3}$ \\ 1, 2, 3 Jurusan Matematika FMIPA Universitas Udayana, Bukit Jimbaran-Bali \\ e-mail: ${ }^{1}$ ajeng.fitrahsani@gmail.com, ${ }^{2}$ taritastrawati@yahoo.com, \\ ${ }^{3}$ sairameka.diva@gmail.com
}

\begin{abstract}
Sanur village is one of beautiful tourism spots in Bali. Sanur is located in south of Bali, Indonesia. There are many beaches in that place. Besides of beautifulness of it, Sanur potentially to be attacked by Tsunami disaster because of it is location near subduction Zone. It is important to know Tsunami evacuation track. This research tries to give alternative Tsunami evacuation track by using Floyd Warshall algorithm. The result of this research is Tsunami evacuation track in sanur by using Floyd Warshall algotihm
\end{abstract}

Keywords: Floyd Warshall, Dynamic Programming, Jalur Terpendek, Evakuasi, Tsunami

\section{Pendahuluan}

Secara geologi Indonesia berada di jalur "cincin api" (ring of fire) dan tiga lempeng tektonik aktif dunia. Tiga lempeng tersebut saling berdesakan satu dengan yang lain. Lentingan lempeng dapat mengakibatkan terganggunya keseimbangan air laut sehingga terbentuk gelombang Tsunami (BMKG, [1]: 7).

Sanur merupakan salah satu objek wisata pantai yang indah di Bali, Indonesia. Bali terletak sangat dekat dengan zona tumbukan antara Lempeng Indo-Australia dan Lempeng Eurasia. Zona tumbukan kedua lempeng tersebut akan memengaruhi khususnya bagian selatan Pulau Bali salah satunya Sanur. Diperkirakan bahwa, gelombang Tsunami hanya memerlukan 30 hingga 60 menit untuk mencapai pantai (GTZ, [2]: 3). Untuk itu betapa pentingnya mengetahui jalur evakuasi Tsunami di daerah yang berpotensi terjadinya bencana tersebut.

Dalam penilitian ini, dicoba dicari jalur terpendek evakuasi Tsunami dengan menggunakan algortima Floyd Warshall. Algoritma Floyd Warshall adalah algoritma penghitungan jalur terpendek yang dapat mencari semua jarak dari tiap simpul (all pairs shortest path) yang artinya dapat digunakan untuk menghitung bobot terkecil dari semua jalur yang menghubungkan sebuah pasangan titik, dan melakukannya sekaligus untuk semua pasangan titik Purwananto [3].

\footnotetext{
${ }^{1}$ Mahasiswa Jurusan Matematika FMIPA Universitas Udayana

${ }^{2,3}$ Staf Pengajar Jurusan Matematika FMIPA Universitas Udayana
} 
Rumusan masalah dari penelitian ini adalah:

a. Bagimana jalur terpendek yang dapat dilalui masyarakat kelurahan sanur untuk menuju zona aman evakuasi dengan menggunakan algoritma Floyd warshall?

b. Manakah jalur terpendek dari titik evakuasi ke masing-masing zona aman evakuasi?

Berdasarkan latar belakang dan rumusan masalah yang telah dipaparkan sebelumnya, maka tujuan dari penelitian ini adalah untuk mengetahui jalur terpendek evakuasi Tsunami yang dapat dilalui oleh masyarakat di Kelurahan Sanur untuk menuju zona aman (titik berkumpul) dengan menggunakan algoritma Floyd warshall dan mengetahui jalur terpendek dari titik evakuasi ke masingmasing zona aman evakuasi.

\section{Metode Penelitian}

Data kuantitatif dalam penelitian ini adalah hasil pengukuran jarak jalurjalur dari titik evakuasi menuju zona aman. Data kualitatif dalam penelitian ini berupa peta evakuasi Tsunami yang diperoleh dari Badan Penanggulangan Bencana Daerah (BPBD) Provinsi Bali. Teknik pengumpulan data yang digunakan dalam penelitian ini meliputi, observasi, dokumentasi, literatur, dan wawancara. Variabel penelitian yang digunakan dalam penelitian ini adalah jarak dari setiap jalur-jalur yang mungkin dapat dilalui dari pantai-pantai yang berada di Kelurahan Sanur yaitu Pantai Segara $\left(V_{3}\right)$, Pantai Shindu $\left(V_{8}\right)$, Pantai Karang $\left(V_{19}\right)$, Pantai Duyung $\left(V_{20}\right)$, Pantai Semawang $\left(V_{26}\right)$, dan Pantai Cemara $\left(V_{29}\right)$ untuk menuju zona aman di Puskesmas III Denpasar Selatan $\left(V_{4}\right)$, dan SMK Negeri 3 Denpasar $\left(V_{33}\right)$.

\section{Hasil dan Pembahasan}

Peta yang diperoleh ditransformasikan ke dalam bentuk graf serta diberi bobot sesuai dengan jarak hasil pengukuran dari satu simpul ke simpul yang lain.

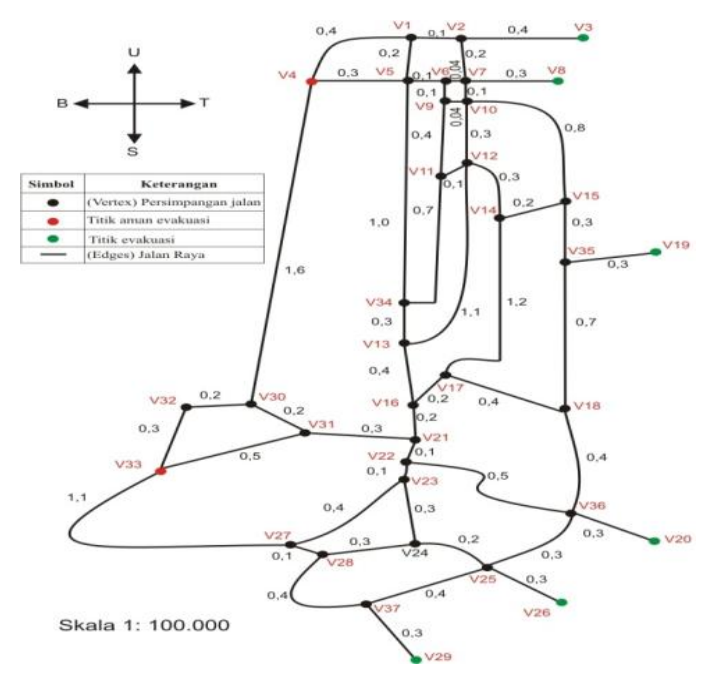

Gambar 1. Representasi Peta Kelurahan Sanur kedalam Bentuk Graf ( Satuan Kilometer ) 
Hasil transformasi graf direpresentasikan ke dalam bentuk matriks ketetanggaan dan diproses dengan menggunakan Algoritma Floyd Warshall

Algoritma Floyd Warshall untuk mencari path terpendek (Siang, [4]: 301): Dimisalkan $W_{0}$ adalah matriks ketetanggaan awal graf berarah berbobot. $W^{*}$ adalah matriks ketetanggaan berbobot terpendek dengan $W_{i j}$ sama dengan path terpendek dari titik $v_{i}$ ke $v_{j}$.

1) $W=W_{0}$

2) Untuk $k=1$ hingga $n$, lakukan:

Untuk $i=1$ hingga $n$, lakukan:

Untuk $j=1$ hingga $n$ lakukan:

3) Jika $W[i, j]>W[i, k]+W[k, j]$ maka

Tukar $W[i, j]$ dengan $W[i, k]+W[k, j]$

4) $W^{*}=W$

\section{Iterasi untuk $k=1$}

Pada setiap elemen matriks $W$ dilakukan pengecekan apakah $W[i, j]>$ $W[i, k]+W[k, j]$. Jika ya, maka ganti $W[i, j]$ dengan $W[i, k]+W[k, j]$. Contoh : $W[1,2]=0,1$, sedangkan $W[1,1]+W[1,2]=\infty+0,1=\infty$

Karena $W[1,2] \ngtr W[1,1]+W[1,2]$ maka bobot $W[1,2]$ tidak diubah.

$W[2,4]=\infty$, sedangkan $W[2,1]+W[1,4]=0,1+0,4=0,5$.

Karena $W[2,4]>W[2,1]+W[1,4]$, maka bobot $W[2,4]$ diubah menjadi 0,5 . Berarti, ada path dari $V_{2}$ ke $V_{4}$ melalui $V_{1}$ yang mempunyai bobot lebih kecil yaitu path $V_{2} V_{1} V_{4}$ dengan jumlah bobot 0,5 . Kemudian dengan cara yang sama, harga $W[i, j]$ dihitung untuk setiap $i$ dan $j$. Penghitungan iterasi dilakukan hingga iterasi $k=37$.

Untuk mengetahui jalur terpendek dari setiap titik evakuasi menuju zona aman maka perhatikan perubahan bobot dari setiap iterasi. Misalnya dari titik evakuasi Pantai Segara $\left(V_{3}\right)$ menuju zona aman evakuasi yang berada di Puskesmas III Denpasar Selatan $\left(V_{4}\right)$ :

Pada iterasi $k=37$, jarak terpendek dari $\left(V_{3}\right)$ ke $\left(V_{4}\right)$ sebesar $0,9 \mathrm{~km}$. Hal ini berarti terdapat jalur-jalur sejauh $0,9 \mathrm{~km}$ untuk menuju zona aman evakuasi di $\left(V_{4}\right)$. Lakukan pengecekan dari $\left(V_{3}\right)$ ke $\left(V_{4}\right)$ pada setiap $k$ untuk mengetahui perubahan setiap bobotnya. $\left(V_{3}\right)$ ke $\left(V_{4}\right)$ memiliki bobot $0,9 \mathrm{~km}$ pada saat $k=2$ hal ini berarti terdapat jalur terpendek dari $\left(V_{3}\right)$ ke $\left(V_{4}\right)$ melalui $\left(V_{2}\right)$. Kemudian perhatikan graf untuk mengetahui $\left(V_{3}\right) \rightarrow\left(V_{2}\right) \rightarrow\left(V_{4}\right)$ telah terhubung. Verteks $\left(V_{3}\right)$ ke $\left(V_{2}\right)$ telah terhubung, sedangkan verteks $\left(V_{2}\right)$ ke $\left(V_{4}\right)$ belum terhubung. Ini berarti belum diketahui verteks penghubung dari verteks $\left(V_{2}\right)$ ke $\left(V_{4}\right)$. Pada 
iterasi $k=37$, jarak terpendek dari $\left(V_{2}\right)$ ke $\left(V_{4}\right)$ sebesar $0,5 \mathrm{~km}$. Lakukan pengecekan dari $\left(V_{2}\right)$ ke $\left(V_{4}\right)$ pada setiap $k$ untuk mengetahui perubahan setiap bobotnya. $\left(V_{2}\right)$ ke $\left(V_{4}\right)$ memiliki bobot $0,5 \mathrm{~km}$ pada saat $k=1$ hal ini berarti terdapat jalur terpendek dari $\left(V_{2}\right)$ ke $\left(V_{4}\right)$ melalui $\left(V_{1}\right)$. Perhatikan graf kembali untuk mengetahui $\left(V_{2}\right) \rightarrow\left(V_{1}\right) \rightarrow\left(V_{4}\right)$ telah terhubung. $\left(V_{2}\right),\left(V_{1}\right),\left(V_{4}\right)$ telah terhubung, sehingga pengecekan selesai. Diperoleh jalur terpendek dari $\left(V_{2}\right)$ ke $\left(V_{4}\right)$ yaitu $\left(V_{3}\right) \rightarrow\left(V_{2}\right) \rightarrow\left(V_{1}\right) \rightarrow\left(V_{4}\right)$ sejauh $0,9 \mathrm{~km}$.

Tabel 1. Hasil Pemrosesan dengan Menggunakan Algoritma Floyd Warshall dari Titik-titik Evakuasi Menuju SMK Negeri 3 Denpasar $\left(V_{33}\right)$.

\begin{tabular}{|c|l|l|c|}
\hline \multicolumn{1}{|c|}{ Zona Aman } & Titik Evakuasi & \multicolumn{1}{|c|}{ Jalur } & Jarak (km) \\
\hline \multirow{2}{*}{$\begin{array}{c}\text { Puskesmas III } \\
\text { Denpasar Selatan }\end{array}$} & Segara (V3) & V3, V2, V1, V4 & 0.9 \\
\cline { 2 - 4 } & Shindu (V8) & V8, V7, V6, V5, V4 & 0.74 \\
\cline { 2 - 4 } & Karang (V19) & V19, V35, V15, V10, V7, V6, V5, V4 & 1.94 \\
\cline { 2 - 4 } & Duyung (V20) & V20, V36, V22, V21, V31, V30, V4 & 3 \\
\cline { 2 - 4 } & Semawang (V26) & V26, V25, V24, V23, V22, V21, V31, V30, V4 & 3.1 \\
\cline { 2 - 4 } & Cemara (V29) & V29, V37, V25, V24, V23, V22, V21, V31, V30, V4 & 3.5 \\
\hline
\end{tabular}

Tabel 2. Hasil Pemrosesan dengan Menggunakan Algoritma Floyd Warshall dari Titik-titik Evakuasi Menuju SMK Negeri 3 Denpasar $\left(V_{33}\right)$.

\begin{tabular}{|c|l|l|c|}
\hline Zona Aman & Titik Evakuasi & \multicolumn{1}{|c|}{ Jalur } & Jarak (km) \\
\hline \multirow{2}{*}{$\begin{array}{l}\text { SMK Negeri 3 } \\
\text { Denpasar (V33) }\end{array}$} & Segara (V3) & V3, V2, V1, V4, V30, V32, V33 & 3 \\
\cline { 2 - 4 } & Shindu (V8) & V8, V7, V6, V5, V4, V30, V32, V33 & 2.84 \\
\cline { 2 - 4 } & Karang (V19) & V19, V35, V18, V17, V16, V21, V31, V33 & 2.6 \\
\cline { 2 - 4 } & Duyung (V20) & V20, V36, V22, V21, V31, V33 & 2 \\
\cline { 2 - 4 } & Semawang (V26) & V26, V25, V24, V23, V22, V21, V31, V33 & 1.8 \\
\cline { 2 - 4 } & Cemara (V29) & V29, V37, V28, V27, V33 & 1.9 \\
\hline
\end{tabular}

\section{Kesimpulan}

1) Telah berhasil dibentuk jalur-jalur terpendek evakuasi Tsunami di Sanur dengan menggunakan Algortima Floywd Warshall.

2) Dapat disimpulkan titik-titik awal evakuasi yang berada di Pantai Segara, Shindu, dan Karang memiliki jarak evakuasi lebih dekat apabila menuju Puskesmas III Denpasar Selatan dibandingkan ke zona aman evakuasi yang berada di SMK Negeri 3 Denpasar sebaliknya, titik-titik awal evakuasi yang berada di Pantai Duyung, Semawang, dan Cemara memiliki jarak evakuasi terdekat di SMK Negeri 3 Denpasar. 


\section{Daftar Pustaka}

[1] BMKG. 2010. Buku Pedoman Pelayanan Peringatan Dini Tsunami INATEWS. Jakarta: Badan Meteorologi, Klimatologi, dan Geofisika (BMKG) dan GTZ-IS GITEWS.

[2] GTZ. 2009. Dokumen Teknis Peta Bahaya Tsunami Bali. Bali: Kelompok Kerja Bali untuk Pemetaan Bahaya Tsunami.

[3] Purwananto, Yudhi., Diana Purwitasari, dan Agung Wahyu Wibowo. 2005. implementasi dan Analisis Algoritma Pencarian Rute Terpendek di Kota Surabaya. Dalam Penelitian dan Pengembangan Telekomunikasi Vol 10 No. 2:94-101. Surabaya: Institut Teknologi Sepuluh November.

[4] Siang, Jong Jek. 2009. Matematika Diskrit dan Aplikasinya pada Ilmu Komputer. Yogyakarta: Andi Offset. 